\title{
The contribution of the ESP teacher to the development of the use of English in Algerian companies
}

A case study, Sonatrach

\section{Kamel Khaldi}

\section{OpenEdition}

Journals

Édition électronique

URL : http://journals.openedition.org/asp/3782

DOI : $10.4000 /$ asp.3782

ISSN : 2108-6354

\section{Éditeur}

Groupe d'étude et de recherche en anglais de spécialité

\section{Édition imprimée}

Date de publication : 1 décembre 1995

Pagination : 207-216

ISSN : 1246-8185

Référence électronique

Kamel Khaldi, «The contribution of the ESP teacher to the development of the use of English in Algerian companies », ASp [En ligne], 7-10 | 1995, mis en ligne le 30 septembre 2013, consulté le 10 décembre 2020. URL : http://journals.openedition.org/asp/3782 ; DOI : https://doi.org/10.4000/asp. 3782

Ce document a été généré automatiquement le 10 décembre 2020.

Tous droits réservés 


\title{
The contribution of the ESP teacher to the development of the use of English in Algerian companies
}

\author{
A case study, Sonatrach
}

\section{Kamel Khaldi}

1 This paper is a brief account of an investigation which was carried out for the benefit of the Language Service of the Algerian Oil Company, Sonatrach in order to evaluate/assess the various courses in English they are presently offering.

\section{Background}

2 It is the first time ever that University teachers in Algeria, and more especially ESP Teachers, together with a company have put their efforts together in order to look into the problems encountered in the teaching of English, in order to come up with suggestions which could improve the present situation.

3 This collaboration illustrates the ways in which the University can contribute to the development of the use of English in public and private companies, and it is of mutual benefit for the company which needs the expertise of the ESP Teacher in terms of course evaluation, needs analysis, course design, testing, and so on; and for the University itself, because it helps it come out of its "ivory tower" and keep in touch with the realities of the economic environment in which it evolves.

4 Such a collaboration is even more crucial since Algeria has witnessed in the past few years a complete reversal in its educational policy, which had been until recently, the exclusive monopoly of the state. With the liberalisation of the economy, private schools, language schools in particular, are now mushrooming. 
Unfortunately, because of a total lack of control, learners' expectations are rarely met, since these schools have neither the qualified staff to run them, nor the qualified teachers to ensure quality in the courses being offered.

Luckily, the Language Service at Sonatrach, the National Oil Company, the largest public sector in Algeria, is run by highly professional people, who have been trained as teachers of English and whose concern for quality and efficiency is a permanent worry. However, despite their dedication to the task, the courses they run have met with great difficulty. As an illustration of this difficulty we can mention the steady decline in the number of learners who attend their courses. As in example, in 1993-1994, out of 150 learners registered at the beginning of the year, only 90 of them were still studying in June, this means a wastage of nearly $60 \%$.

7 Our aim in this investigation therefore, was to identify the causes of the problems the learners were encountering, and, eventually, come up with suggestions that would help towards an improvement of the teaching situation.

8 In order to arrive at a clear identification of these causes we used a series of questionnaires aimed at the teachers and the learners, and an interview aimed at the managers of the Language Service. Our general objectives in using these research tools were twofold:

9 (i) To arrive at a detailed analysis of the present teaching situation, in terms of teachers, educational managers, and learners, and

10 (ii) To analyse both learners and their institutions' needs (i.e., target situation analysis), and in view of establishing as detailed a profile as possible of the intended teaching situation.

\section{The present situation analysis}

11 Before looking at the problems themselves, I think it would proper to say a few words about the overall organisation of the Language Service and the courses they offer.

\subsection{The Language Service at Sonatrach}

12 This Service is run by three graduates in English who have been working with Sonatrach for at last ten years. Their main task is to run the service but they sometimes share in the teaching. They run various courses in English for different levels of proficiency which are coded as follows (see table 1).

Table 1

\begin{tabular}{|l|l|}
\hline 'A' Beginners & 'D' Advanced \\
\hline 'B' Intermediate & 'E' Prepares for the FCE Exam \\
\hline 'C' Post Intermediate & 'F' Prepares for the Cambridge Proficiency exam \\
\hline
\end{tabular}


Each group is given four hours every week during nine months (October-June), which amounts to approximately 140 hours per session, which is well within the admitted norms for a particular level.

Learners are tested regularly (Contrôle Continu). Results in tests and their progress in the course are reported to employer firms regularly.

All the learners either belong to Sonatrach itself, in which case tuition is free of charge, or to other companies in which case the latter, and not their employees, pay fees which are relatively low when compared to those practised in the private sector. It is important to mention that all these companies see these courses as in-service training and thus, irregular attendance may entail the learners withdrawal from the course.

\subsection{The research proper}

6 As already mentioned the aim of this investigation was to arrive at a comprehensive assessment of the parameters involved in the present teaching situation in order to identify the problems and come up with recommendations/suggestions for the improvement of the teaching situation. For this purpose, we devised a certain number of research tools:

7 First, a questionnaire aimed at the teachers in view of establishing:

- The teachers and their background (in terms age group, training, qualifications, teaching experience, and so on).

- The general teaching conditions in which they worked (classroom size, equipment available, teaching materials, and so on).

- Their awareness of the teaching situation in which they were involved (i.e., how are learners selected, grouped into various groups, do they have specific needs).

Second, an interview with the managers of the Language Service the aim of which was to discover:

- The number of registered learners and their backgrounds in terms of degree(s) held, their qualifications, their position in the Company they worth worked in, and so on.

- The procedure that learners had to follow in order to register for a particular course, and the ensuing decision taken by the Language Service in order to put them into the group which assumingly corresponded to their level of proficiency.

- Whether there was any prior investigation of the learners' or their company's motivations for undertaking such a course.

- The rationale behind the selection of the teaching materials, and

- The criteria used for recruiting the teachers

\subsection{The results of the questionnaire}

The results show that the Service employs eight teachers, ( 3 male and 5 female), three of whom are University Lecturers (two of them hold a Magister, and one a Ph.D), and the remaining five are secondary school teachers, i.e., licence holders. None of them works on a permanent basis. The average teaching experience is approximately ten years. The age range is between 35 and 45 . The average number of teaching hours is between eight and ten per teacher. 
Teaching conditions are nearly perfect, since groups are relatively small (between 12 and 20), in addition the Language Service provides all the facilities teachers may need: photocopying machines, radio cassettes, tape recorders, video recorders, library, Satellite TV which can receive all stations broadcasting in English (CNN, SKY TV).

21 The teaching materials are all original textbooks imported from Britain and provided free to all learners (see Table 2).

Table 2: Textbooks used

\begin{tabular}{|l|l|l|}
\hline Level & $\begin{array}{l}\text { Weekly } \\
\text { hours }\end{array}$ & Textbook used \\
\hline B & 4 & John and Liz Soars, 1989, Headway, Oxford University Press \\
\hline C-D & 4 & Headway, Upper Intermediate \\
\hline E & 4 & Headway, Advanced \\
\hline F & 4 & $\begin{array}{l}\text { Leo Jones, 1983, Progress towards First Certificate, Cambridge University } \\
\text { Press }\end{array}$ \\
\hline
\end{tabular}

Thus, as far as teacher qualification, working conditions and teaching materials are concerned, the Language Service has almost perfect conditions, which many other institutions would quite rightly envy.

However, despite this seemingly ideal situation, our questionnaire helped us to identify many potential problems.

None of the teachers had been associated in the selection of the teaching materials.

None of them had been associated with the evaluation of the learner's proficiency in order to place them into a particular group. This decision was made by the Language Service without any placement test being held, and as our interview will show, learners usually place in a particular level either on the basis of their previous study records when they were former learners in the Service (approximately 50\% of the learners), or on the basis of the evaluation that learners made about their own proficiency.

The teachers were not given any specific information concerning the professional background of their learners (qualifications, position held, any particular needs, and so on).

The most important problem raised, in our view, was that none of the teachers who were questioned had had any experience with ESP, either in terms of the theoretical background of the field, or in terms of the teaching itself. This lack is probably due to the fact that the study of ESP is not included the curriculum of the Licence d'anglais. Given such a crying lack in their training, one would be justified to assume that, inevitably such teachers will run into major difficulty when confronted to an ESP situation, which is the case here.

The consequences which follow from these problems are manifold: first, learners who come with different needs, and sometimes different levels of proficiency, are put in the 
same group, and given the same type of teaching, exclusively concerned with general English.

The second consequence of this not very pedagogical procedure is the lack of homogeneity in the level of the students within the same group, which led teachers to upgrade or scale down some of their learners a few weeks after the course started.

\subsection{Results of the interview with the managing staff}

Our interview with the managerial staff of the Language Service showed that many of the decisions which were taken already contained the seeds of the problems they presently encounter.

31 First, consequences of the decisions which were made about the learners:

There were too many discrepancies in the learners' backgrounds not only in terms of their proficiency in English, but also and even more importantly, in terms of

(i) the various Companies which they came from, for example, Sonatrach with its various subsidiary divisions (exploration, marketing, finances, etc.), Sonelgaz, (Electricity Generating Board), various banks and so on,

(ii) the position/occupation they held in these companies (Managers, Technicians, Engineers, Secretaries).

(iii) their company's as well as their own needs in English.

Second, there were the consequences of the procedure used in selecting candidates and grouping them into different levels of proficiency.

The division into six (06) levels (A-F) seemed to have no rationale except maybe on purely intuitive/subjective grounds. Furthermore, there seems to be no justification, for instance, for maintaining groups like ' $E$ ' and ' $F$ ', for the FCE and Proficiency respectively, since the British Council, which was the only Approved Examining Centre, closed its doors at the beginning of this year.

Third, the consequences following the choice of teaching materials

Despite the fact that the Resource Centre of the Language Service is richly provided with a large variety of textbooks, teaching materials, supplementary readers, videos, tapes and so on, it nevertheless seems that their purchase did not obey any sound pedagogical criteria, since it does not cater for the specific needs of the learners.

Finally, consequences following the recruiting of the teachers

If the qualifications and teaching experience of the teachers presently employed is beyond any criticism, one is nevertheless bound to express some doubt about their efficiency since their main concern is the teaching of general English, whereas the situation in which they are involved is a typical ESP situation and therefore requires a different approach in terms of teaching methodology, teaching materials, awareness of and attendance to learners' specific needs.

\section{The target situation analysis}

It is now quite obvious that the present course is far from catering either for the needs of the learners or for the needs of the institution which employ them? 
The questionnaires administered to the learners show that nearly all of them are satisfied with the quality of the teaching, the teaching materials which they find very interesting and attractive, the general study conditions, the very competent teachers, the availability of a library, various teaching aids, and so on.

2 However, most of them expressed their unhappiness with the general objectives of the Course which they rightly saw as exclusively concerned with the teaching of general English, while they would have liked to see more job-related type of English being taught. For instance, some of them need English for reading and understanding specialised documentation, while others need English for attending conferences abroad, others for answering mail (i.e., writing), others for translating various documents, and so on.

The feeling that they were missing an aspect of the language they perceived as very important and relevant created a feeling of frustration which did have an effect on their motivation for continuing the course throughout the year. Furthermore, they all recognised the fact that the main reason their respective companies had accepted their registration in this course was that it would enable them to acquire language skills they could use immediately so that it would increase their efficiency in the position they held in the company.

44 Thus, on the basis of all these findings about teachers, learners and managerial staff, we were led to make a series of recommendations which can be summed up under five main headings: Teachers, Learners, Structure of the course, Teaching materials and Evaluation procedure.

\section{Teachers}

45 Although the competence of the teachers presently employed in the Language Service is beyond any criticism, it remains true however that the lack of awareness about the specific needs of their learners and their unfamiliarity with the methodology involved in detecting these needs turns out to be a great handicap in their teaching. This, in the long term, may have, and did certainly have in the past, a demotivating effect on the learners.

We would therefore recommend that they be offered opportunities for in-service training in ESP. This could be taken care of by University ESP teachers who would familiarise them with

(i) the origins and development of ESP,

(ii) notions about how to carry out an analysis of Learners' Needs,

(iii) The issues involved in the management of an ESP Course, and

(iv) training in/familiarisation with the materials to be used in the Specialised English Course

\section{Learners}

51 At this level, we think that there are two main problems which need attending to very urgently.

First, the placement procedure needs to be carried out on a more rational basis, i.e., use a standardised placement test which would be more reliable in showing the actual level of performance in English so that learners are put into groups that correspond to their actual level of proficiency. 
As our investigation shows, the structure of the course is currently far from being efficient. Our suggestion is to remodel the Course in a completely different way, which would offer more choice to the learners and more flexibility to the managers of the Language Service. The overall Course could be divided into the following main components:

\section{First component}

A Common Core Course, exclusively concerned with the teaching of General English lasting from one to three years, depending on the level of the learner. This would include all learners independently from their specialised needs. It could be organised as follows: Year One: Beginners; Year Two: Intermediate; Year Three: Advanced.

\section{Second component}

57 Specialised English Course(s) lasting one year. During this year learners would acquire and practice language which is more specifically related to their occupation.

This component, according to the survey we carried out, should include the following topics because they are the most sought after: English for Management, English for Engineers and English for Secretaries.

59 This, of course, does not preclude the possibility of including any other speciality if needs be.

60 In order to offer even more flexibility, we suggest that the second component may be completed according to two different options.

Option 1:

61 Keep the present semi-intensive type of teaching (i.e., four hours/weekly, over a nine month period. i.e., 140 hours/year) for all the learners. The number of years they would have to spend in this Common Core Course will vary from one to three years, depending on which point they enter it, and this on the results of the placement test.

62 During this period the teaching will be exclusively concerned with the structures of the language, the development of language skills, the reinforcement of grammatical structures, and the development of the learners' communicative abilities.

63 Then, at the end of the Common Course learners would choose from the available options in specialised English. This Course would be completed over a nine month period at a rate of four hours a week.

64 Thus, completion of the Whole Course (General English plus Specialised English) would vary from Four (04) to One (01) years depending on the entry point of the applicant. Option 2:

65 This option is presently non-existent and we suggest its introduction on an experimental basis with the second component only. 


$$
\begin{aligned}
& \text { rate of five (05) hours/day, during } 25 \text { hours a week. The whole course will then be } \\
& \text { completed in six (06) to seven (07) weeks. }
\end{aligned}
$$
basis. They would come for a whole week each month and tuitions will be provided at a

\section{Teaching materials and methodology}

Following the recommendations concerning the future structure of the course, there will be two types of teaching materials:

A set of teaching materials for the First Component, and we think that the materials presently used, i.e., the Headway series should remain, thus Year One will use Headway Beginners, Year Two will use Headway Intermediate and Year Three will use Headway Post Intermediate.

69 While materials for the second component, appropriate to the needs mentioned above will have to be purchased, and these are widely present on the market.

\section{Evaluation}

The evaluation procedure which is presently used should be maintained since it gives a reliable indication of the student's achievement and progress. Our view however, is that there should be some sort of reward attached to the efforts made by the learner. We suggest that the results be considered as an element in the advancement in their careers. This would increase their motivation in attending such courses.

71 This small-scale research shows the kind of collaboration we would like to see established between ESP teachers and the various institutions (companies or otherwise) which are involved in one way or another in the teaching and use of English.

We believe that such a close cooperation will be beneficial for both sides: the institutions will find the necessary expert advice for the design and implementation of their courses, ensuring therefore greater efficiency in their teaching, and the teachers will have an opportunity to apply their know-how, in order to guarantee the quality of the teaching being offered.

\section{BIBLIOGRAPHIE}

Hutchinson, T. S. and A. Waters. 1988. A Learning Centred Approach Cambridge: Cambridge University Press.

Kennedy, C. and R. Bolitho. 1984. English for Specific Purposes. London: MacMillan.

Robinson, P.C. 1991. ESP: A Practioner's Guide. London: Prentice Hall.

Swales J. 1985. Episodes in ESP. Cambridge: Cambridge University Press. 


\section{RÉSUMÉS}

Le présent article présente les résultats d'une recherche-action conduite pour améliorer la formation continue en anglais de spécialité des personnels d'une grande entreprise du secteur public algérien.

This article comments on the results of an action-research study carried out to improve the inservice training in ESP of the staff of a large public-sector company in Algeria.

\section{INDEX}

Mots-clés : Algérie, anglais de spécialité, conception de cours

Keywords : Algeria, course design, ESP

\section{AUTEUR}

\section{KAMEL KHALDI}

Kamel Khaldi teaches at University of Algiers. 